\title{
An assessment of copper-contaminated soil using Kenaf (Hibiscus cannabinus I.) as a phytoaccumulator
}

\author{
Talha I. Z. ${ }^{1}$, Abba Mani F. ${ }^{1}$ and Ismaila M. ${ }^{*}$ \\ ${ }^{1}$ Department of Agricultural Technology, School of Agricultural Sciences and Technology, Ramat Polytechnic, P M B \\ 1070, Maiduguri, Nigeria. \\ 2Department of Agricultural Technology, Yobe State College of Agriculture, Gujba, PMB 1104, Damaturu, Nigeria. \\ *Corresponding author. Email: ismimoh@gmail.com
}

Copyright @ 2018 Talha et al. This article remains permanently open access under the terms of the Creative Commons Attribution License 4.0, which permits unrestricted use, distribution, and reproduction in any medium, provided the original work is properly cited.

Received 2nd April, 2018; Accepted 15th May, 2018

\begin{abstract}
A pot experiment was conducted to study the potentials of Kenaf (Hibiscus cannabinus L.) as a Copper (Cu) phytoaccumulator at different levels of artificial contamination. Copper was applied as cupric sulphate $\left(\mathrm{CuSO}_{4} .5 \mathrm{H}_{2} \mathrm{O}\right)$ and the treatments were $0,50,100$ and $150 \mathrm{mg} \mathrm{kg}^{-1}$ of Cu. Kenaf was grown in each of the treated pots for 10 weeks, following which, leaf, stem and root samples were collected and analysed for $\mathrm{Cu}$ contents. The soil was analysed for physicochemical properties [viz. pH, electrical conductivity (EC), organic carbon (OC), exchangeable acidity (EA), exchangeable cations $\left(\mathrm{Ca}^{2+}, \mathrm{Mg}^{2+}, \mathrm{Na}^{+}, \mathrm{K}^{+}\right)$and extractable and total $\mathrm{Cu}$ contents) before treatments/contamination and after harvesting. Kenaf showed symptoms of toxicity at 100 and $150 \mathrm{mg} \mathrm{kg}^{-1}$ treatments of $\mathrm{Cu}$. It was observed that, compared with the levels of contamination of $\mathrm{Cu}$, the concentration in kenaf was generally insignificant; thus, the concentration reduction in the soil at one cycle of cropping may not berealistic. Copper treatments at different levels significantly changed soil $\mathrm{pH}$ and EC. Therefore, more cycles of growth are needed to effectively remediate Cucontaminated soils using Kenaf as Cu phytoaccumulator.
\end{abstract}

Key words: Copper, heavy metals, Kenaf, phytoaccumulator, phytoremediation, soil contamination.

\section{INTRODUCTION}

The concept of soil protection has recently received considerable attention around the globe due to the need to realise food security for the growing population. Contamination of soil by heavy metals was described by Logan (1990) as soil chemical degradation. Soil chemical degradation is caused by the build-up of some toxic chemicals and an elemental imbalance that is injurious to plant growth (Abrol et al., 2012).

Heavy metal contamination in the soil-water-plant ecosystem is of great concern because of its possible influence on the food chain (Mmolawa et al., 2010; Zakir et al., 2012). In the soil system, pollution by toxic metals is due to both natural processes, such as weathering of minerals, and anthropogenic activities related to industry, agriculture, burning of fossil fuels, vehicular emissions, mining and metallurgical processes and their waste disposal, as is the case in Nigeria (Human Rights Watch
Staff, 2013). Mainly due to their harmful effects on plants, heavy metals have received enormous attention all over the world.

Pollution of the natural environment by heavy metals has become a global phenomenon, as these metals are indestructible, and most of them have toxic effects on living organisms when they exceed a certain concentration (Dalman et al., 2006; Ghrefat and Yusuf, 2006). Furthermore, heavy metals present a serious environmental risk when they accumulate in soils, especially for regions undergoing fast industrialisation and urbanisation (Zakir et al., 2017; Begum et al., 2014; Bakali et al., 2014; Hu et al., 2013). This implies a health risk, linked with the spread of pollution to agricultural areas, that poses a serious environmental threat and concern (Haque et al., 2018; Aysha et al., 2017; Tahar and Keltoum, 2011; Tahar et al., 2014). 
Copper $(\mathrm{Cu})$ is among the most frequently reported heavy metals concerning its potential hazards and occurrence in soils. It has a high affinity for soluble organic ligands, and the formation of these complexes may greatly increase Cu's mobility in soil. Its accumulation in topsoil is greatly influenced by traffic volume (Al-Kashman and Shawabkeh, 2009). In Maiduguri, Nigeria, the recent practice by many companies and industries of discharging untreated sewage, refuse and industrial wastewaters into nearby agricultural fields, as well as the indiscriminate dumping of refuse in neighbourhoods by inhabitants, indicate little concern related to environmental conservation in this area. These activities help in causing the accumulation of heavy metals like $\mathrm{Cu}$ in agricultural fields.

Phytoremediation, the use of living green plants specialized in cleaning up polluted soil (Singh et al., 2015), has become indispensable for addressing the problem of heavy metals in soils. Risk reduction may involve a process of removal, degradation or containment of a contaminant, or it may comprise a combination of any of these factors; hence, the understanding of different forms of phytoremediation will help in determining the different processes that occur due to vegetation, what happens to a contaminant, where the contaminant occurs and what should be done for effective phytoremediation (Pivetz, 2001). Phytoremediation is extremely competitive in relation to other treatment alternatives, as it is simple to use and has high public acceptability (Kaushik, 2015).

Several plant species have been used, assessed and ultimately reported to exhibit good performance in cleaning up soil and water and a natural propensity to take up metals, such as $\mathrm{Cu}$ and $\mathrm{Pb}$ (Singh et al., 2015). The potential of kenaf (Hibiscus cannabinus L.) and corn (Zea mays L.) for accumulating some heavy metals has been tested elsewhere for the remediation of dredging sludge contaminated with trace metals (Arbaoui et al., 2013). However, there has been no report on the use of kenaf as a phytoaccumulator in Borno State's (Nigeria) sandy loam. Therefore, the objectives of the study were to determine: the effects of $\mathrm{Cu}$ treatments on some physicochemical characteristics of soil along with the growth performance of Kenaf (Hibiscus cannabinus L.) and to assess its potentiality as $\mathrm{Cu}$ phytoaccumulator.

\section{MATERIALS AND METHODS}

\section{Soil}

To examine the potentials of Kenaf (Hibiscus cannabinusL.) as a phytoaccumulator of $\mathrm{Cu}$, composite soil samples were used and the texture of the soil was sandy loam. The soil samples were collected from the teaching and research farm of the Faculty of Agriculture, University of Maiduguri at random at 25 different locations across the field at 0 to $30 \mathrm{~cm}$ depths. Large soil lumps were crushed, and the samples were passed through a 2-mm sieve to remove plant remains and materials larger than 2 $\mathrm{mm}$. The sieved samples were kept in polythene bags. Tables 1 and 2 present the characteristics of the collected soil samples.

\section{Treatments and experimental design}

The study was conducted in a pot experiment which was laid in a completely randomized design (CRD). Copper (Cu) was used as treatments at four (4) different levels with three (3) replications. Cu was applied as cupric sulphate ( $\mathrm{CuSO}_{4} .5 \mathrm{H}_{2} \mathrm{O}$ ) by wet contamination method at levels of treatments based on common ranges of metal contamination as given by Lindsay (1979) for contaminated soils. The treatments includes: $0,50,100$ and $150 \mathrm{mg} \mathrm{kg}^{-1} \mathrm{Cu}$. Basal nutrients of $\mathrm{N}, \mathrm{P}$ and $\mathrm{K}$ were prepared and applied to meet the $\mathrm{N}, \mathrm{P}, \mathrm{K}$ requirements of the potted plants. One hundred $\mathrm{mg} \mathrm{kg}^{-1}$ of $\mathrm{N}$ was applied as ammonium nitrate $\left(\mathrm{NH}_{4} \mathrm{NO}_{3}\right)$, One hundred $(100) \mathrm{g} \mathrm{Kg}$ ${ }^{1} \mathrm{P}$ was applied as calcium hydrogen phosphate and 50 $\mathrm{mg} \mathrm{kg}^{-1} \mathrm{~K}$ was applied as potassium chloride $(\mathrm{KCl})$. After treatment, soils were kept for one week for incubation, and then seven certified seeds of Kenaf were planted per pot and watered at $10 \mathrm{KPa}$ with distilled water and three days after planting, seedlings were thinned from 7 to 5 stands per pot, based on vigour to avoid overcrowding. Data collected includes- date of planting, weekly plant height (tape measurement), general physical appearance, blooming and harvest dates. During the growth period, soil water content was kept at $90 \%$ of field capacity and corrected daily by weight. Weeds were immediately handpicked once emerged; growth period of experimental plant was 10 weeks after which plants were harvested.

\section{Laboratory analysis}

Soil $\mathrm{pH}$ and electrical conductivity (EC) were measured using 1:2.5 soil weight to water volume ratio extract according to Thomas (1996). Soil Organic Carbon was determined using the wet oxidation method of Walkley and Black (1934) as reported by Sparks et al. (1996). Soil exchangeable acidity was determined by extracting the soil with $\mathrm{Kcl}$ using the extraction/titration method (McLean, 1965). The exchangeable bases in the soil were extracted with $1 \mathrm{~N}$ neutral ammonium acetate $\left(\mathrm{NH}_{4} \mathrm{OAc}\right)$ buffer according to Sparks et al. (1996). The concentrations of $\mathrm{Na}$ and $\mathrm{K}$ were determined with the flame photometer while that of $\mathrm{Ca}$ and $\mathrm{Mg}$ by Atomic Absorption Spectrophotometer (AAS) model AA-6800 (Shimadzu) (Stover et al., 1976). Determination of extractable and total $\mathrm{Pb}$ and plant $\mathrm{Pb}$ content were determined according to standard procedure using Atomic Absorption Spectrophotometer (AAS) model AA-6800 (Shimadzu) (Stover et al., 1976). 
Table 1. Characteristics of the sampling site.

\begin{tabular}{|c|c|}
\hline Sampling site & Characteristics \\
\hline Coordinates & University of Maidduguri ( $11^{\circ} 54^{\prime} \mathrm{N}$ and $\left.13^{\circ} 15^{\prime} \mathrm{E}\right) 354 \mathrm{~m} \mathrm{ASL}$ (Climate Chart, 2010) \\
\hline Texture & Sandy loam (Soil Survey Staff, 2014) \\
\hline Taxonomic classification & Typic Ustipsamment (Rayar, 1984) \\
\hline Average annual rainfall & 440-600mm (Climate Chart, 2010) \\
\hline Temperature & $15-20^{\circ} \mathrm{C}(\mathrm{Min}) 37-45^{\circ} \mathrm{C}(\mathrm{Max})$ (Climate Chart, 2010) \\
\hline Steady infiltration rate & $135 \mathrm{~mm} / \mathrm{hr}$ (Grema and Hess, 1994) \\
\hline Average bulk density & $1.5 \mathrm{~g} / \mathrm{cm}^{3}($ Grema and Hess, 1994) \\
\hline Topography \& Vegetation & Generally a low and plain topography with short grasses and thorny shrubs \\
\hline
\end{tabular}

Table 2. Initial (before kenaf grown) soil characteristics.

\begin{tabular}{lc}
\hline Soil characteristics & Values \\
\hline $\mathrm{pH}$ & 6.10 \\
$\mathrm{EC}$ & $0.09 \mathrm{dsm}^{-1}$ \\
$\mathrm{OC}$ & $0.24(\%)$ \\
$\mathrm{EA}$ & 0.40 \\
$\mathrm{Ca}^{2+}$ & $13.20 \mathrm{cmolc} \mathrm{kg}^{-1}$ \\
$\mathrm{Mg}^{2+}$ & $6.0 \mathrm{cmol}_{\mathrm{c} \mathrm{kg}}{ }^{-1}$ \\
$\mathrm{Na}^{+}$ & $0.29 \mathrm{cmolc} \mathrm{kg}^{-1}$ \\
$\mathrm{~K}^{+}$ & $0.28 \mathrm{cmol}_{\mathrm{c} \mathrm{kg}}$ \\
$\mathrm{Extr} . \mathrm{Cu}$ & $0.04 \mathrm{mgkg}^{-1}$ \\
Total Cu & $0.64 \mathrm{mgkg}^{-1}$ \\
\hline
\end{tabular}

EA - Exchangeable Acidity, Extr. - Extractable.

\section{Statistical analysis}

All data collected were subjected to statistical analysis using analysis of variance (ANOVA) with the help of a statistical package, statistix 10.0. Difference between treatments was separated using LSD at $5 \%$ probability level.

\section{RESULTS}

\section{Characteristics of soil used}

Physicochemical characteristics of soil used for the pot experiment before contamination with $\mathrm{Cu}$ at various levels and after harvesting of Kenaf are described as follows:

\section{Effects of $\mathrm{Cu}$ treatments on soil characteristics after harvesting of Kenaf}

Soil pH, Electrical Conductivity (EC), Exchangeable Acidity (EA) and percent Organic Carbon content (\%OC) of soils treated with $\mathrm{Cu}$ at various levels are presented in Table 3.
$\mathrm{pH}$ values for soils treated with $\mathrm{Cu}$ ranged from 5.6 to 6.37, the differences amongst the treatments were significant $(P<0.05)$. However, the highest treatment level of $\mathrm{Cu}\left(150 \mathrm{mg} \mathrm{kg}^{-1}\right)$ had significant $(\mathrm{P}<0.01)$ change in $\mathrm{pH}$ (5.46) compared to the control treatment. EC values ranged from 0.13 to $0.33 \mathrm{dsm}^{-1}$, with significant $(P<0.05)$ difference among the treatments.

Soil exchangeable bases (cations) at different levels of $\mathrm{Cu}$ treatments after harvesting of Kenaf is presented in Table 4. Treatments of $\mathrm{Cu}$ at the different levels had no significant $(\mathrm{P}<0.05)$ effects on exchangeable $\mathrm{Ca}^{2+}, \mathrm{Mg}^{+}$, $\mathrm{Na}^{+}$and $\mathrm{K}^{+}$. Values of exchangeable $\mathrm{Ca}^{2+}$ ranged between 1.20 and $1.30 \mathrm{cmol} \mathrm{kg}^{-1}$, values of $\mathrm{Mg}^{2+}$ ranged from 0.53 to $1.50 \mathrm{cmol} \mathrm{kg}^{-1}$. That of exchangeable $\mathrm{Na}^{+}$and $\mathrm{K}^{+}$had values from 0.39 to 0.41 and 0.22 to $0.33 \mathrm{cmol} \mathrm{kg}^{-1}$, respectively.

\section{Effect of $\mathrm{Cu}$ treatments on soil $\mathrm{Cu}$ contents after harvesting of Kenaf}

The extractable and total $\mathrm{Cu}$ contents after harvesting of Kenaf are presented in Table 5. Extractable $\mathrm{Cu}$ of the soil treated with $\mathrm{Cu}$ at the different levels $\left(0\right.$ to $\left.150 \mathrm{mgkg}^{-1} \mathrm{Cu}\right)$ had no significant $(P<0.05)$ changes; values ranged between $0.00 \mathrm{mg} \mathrm{kg}^{-1} \mathrm{Cu}$ to $1.71 \mathrm{mgkg}^{-1} \mathrm{Cu}$. On the other hand, soil total $\mathrm{Cu}$ content significantly $(\mathrm{P}<0.01)$ increased with the increasing levels of $\mathrm{Cu}$ treatments (Table 5).

\section{Effects of $\mathrm{Cu}$ treatments on Kenaf growth and $\mathrm{Cu}$ content}

The weekly heights of Kenaf plant grown in $\mathrm{Cu}$ treated soils at different levels of treatment is presented in Table 6. Values of Kenaf height grown in $\mathrm{Cu}$ treated soils were insignificant $(P<0.05)$. Growth generally was rapid within first three weeks in all the treatments, however, at third and fourth (treatments levels of 100 and $150 \mathrm{mg} \mathrm{kg}^{-1} \mathrm{Cu}$ ), plant growth kept being stunted. At these levels of treatment, plant showed signs of toxicity; plants were become yellow and stunted in growth and in extreme cases some plants 
Table 3. Effects of different treatments of $\mathrm{Cu}$ on soil pH, EC, exchangeable acidity and organic carbon after harvesting of kenaf.

\begin{tabular}{ccccc}
\hline $\begin{array}{c}\text { Treatments } \\
\mathbf{C u}\left(\mathbf{m g k g}^{-1}\right)\end{array}$ & $\mathbf{p H}$ & $\begin{array}{c}\text { Electrical Conductivity } \\
\left.\mathbf{( d m s}^{-1}\right)\end{array}$ & $\begin{array}{c}\text { Exchangeable Acidity } \\
\left(\mathbf{c m o l}_{\mathbf{K}} \mathbf{K g}^{-1}\right)\end{array}$ & Organic Carbon (\%) \\
\hline 0 & 6.33 & 0.13 & 0.67 & 0.39 \\
50 & 6.37 & 0.13 & 0.53 & 0.39 \\
100 & 6.07 & 0.19 & 0.60 & 0.37 \\
150 & 5.60 & 0.33 & 0.73 & 0.28 \\
$\mathrm{LSD}(\mathrm{P}<0.05)$ & 0.37 & 0.12 & $\mathrm{NS}$ & $\mathrm{NS}$ \\
\hline
\end{tabular}

$\mathrm{NS}=$ Not significant.

Table 4. Effect of different treatments of $\mathrm{Cu}$ on exchangeable bases (Cations) after harvesting of kenaf.

\begin{tabular}{|c|c|c|c|c|}
\hline Treatments [Cu $\left.\left(\mathrm{mgkg}^{-1}\right)\right]$ & $\mathrm{Ca}^{2+}\left(\mathrm{cmolc} \mathrm{kg}^{-1}\right)$ & $\mathrm{Mg}^{2+}\left(\mathrm{cmol}_{\mathrm{c}} \mathbf{~ k g}^{-1}\right)$ & $\mathrm{Na}^{+}\left(\mathrm{cmol}_{\mathrm{c} \mathrm{kg}}{ }^{-1}\right)$ & $\mathrm{K}^{+}\left(\mathrm{cmol}_{\mathrm{c}} \mathrm{kg}^{-1}\right)$ \\
\hline 0 & 1.20 & 0.53 & 0.40 & 0.22 \\
\hline 50 & 1.20 & 0.61 & 0.41 & 0.22 \\
\hline 100 & 1.30 & 0.50 & 0.39 & 0.27 \\
\hline 150 & 1.20 & 1.00 & 0.39 & 0.33 \\
\hline $\operatorname{LSD}(P<0.05)$ & NS & NS & NS & NS \\
\hline
\end{tabular}

NS=Not significant.

Table 5. Effect of different treatments of $\mathrm{Cu}$ on soil extractable and total Cu content after harvesting of kenaf.

\begin{tabular}{ccc}
\hline Treatments $\mathbf{C u}\left(\mathbf{m g k g}^{-1}\right)$ & Extractable Metal $\left(\mathbf{m g k g}^{-1}\right)$ & Total Metal $\left(\mathbf{m g k g}^{-1}\right)$ \\
\hline 0 & 0.00 & 0.27 \\
50 & 1.64 & 16.81 \\
100 & 1.71 & 34.36 \\
150 & 1.28 & 42.90 \\
$\mathrm{LSD}(\mathrm{P}<0.05)$ & $\mathrm{NS}$ & 0.26 \\
\hline
\end{tabular}

NS=Not significant.

Table 6. Effects of different treatments of $\mathrm{Cu}$ on weekly height of Kenaf plant.

\begin{tabular}{ccccccccccc}
\hline Treatments & \multicolumn{8}{c}{ Weekly Plant Height of Kenaf Plant (cm) } \\
\cline { 2 - 11 } Cu (mgkg $\left.^{-1}\right)$ & WK 1 & WK 2 & WK 3 & WK 4 & WK 5 & WK 6 & WK 7 & WK 8 & WK 9 & WK 10 \\
\hline 0 & 5.90 & 11.00 & 16.33 & 21.83 & 28.33 & 34.00 & 39.67 & 45.33 & 50.67 & 56.00 \\
50 & 5.73 & 10.17 & 14.73 & 18.60 & 23.50 & 28.67 & 33.33 & 38.33 & 43.33 & 48.00 \\
100 & 5.63 & 9.17 & 13.67 & 17.67 & 22.67 & 27.17 & 31.50 & 36.50 & 43.00 & 44.67 \\
150 & 5.67 & 9.60 & 12.33 & 17.17 & 21.50 & 25.67 & 30.67 & 34.33 & 38.33 & 42.33 \\
LSD (P<.05) & NS & NS & NS & NS & NS & NS & NS & NS & NS & NS \\
\hline
\end{tabular}

NS=Not significant.

died (4 out of the 5 stands of Kenaf plants died at 150 mgkg-1 $\mathrm{Cu}$ in the third replicate). Fresh and dry weight of Kenaf at various treatment levels of $\mathrm{Cu}$ showed significantly $(P<0.05)$ differences (Table 7$)$. It is aparant from Table 7 that both fresh and dry weights of plants decreased with increased levels of Cu treatments.
Total $\mathrm{Cu}$ contents in the different parts of Kenaf plant grown at various treatments showed significantly $(P<$ 0.05) differences (Table 8). At all Cu treatment levels, leaf $\mathrm{Cu}$ content ranged from 0.46 to $2.08 \mathrm{mgkg}-1$; stem $\mathrm{Cu}$ contents varied from 2.22 to $7.13 \mathrm{mgkg}-1$ and root $\mathrm{Cu}$ contents ranged from 0.64 to $10.45 \mathrm{mgkg}-1$. The total plant 
Table 7. Effect of different treatments of $\mathrm{Cu}$ on fresh and dry weights of Kenaf after harvesting.

\begin{tabular}{ccc}
\hline TreatmentsCu $\left(\mathbf{m g k g}^{-1}\right)$ & Plant Fresh Weight $\mathbf{( g )}$ & Plant Dry Weight $\mathbf{( g )}$ \\
\hline 0 & 118.33 & 22.07 \\
50 & 101.67 & 20.67 \\
100 & 91.67 & 16.87 \\
150 & 23.33 & 3.40 \\
LSD $(\mathrm{P}<0.05)$ & 14.88 & 3.74 \\
\hline
\end{tabular}

NS=Not significant.

Table 8. Effect of different treatments on Cu content in different parts of Kenaf plant.

\begin{tabular}{|c|c|c|c|c|c|}
\hline Heavy Meatal & $\begin{array}{l}\text { Levels of } \\
\text { Treatments } \\
\left(\mathrm{mgkg}^{-1}\right)\end{array}$ & $\begin{array}{c}\text { Leaf Metal } \\
\text { Content } \\
\left(\mathrm{mgkg}^{-1}\right)\end{array}$ & $\begin{array}{c}\text { Stems Metal } \\
\text { Content } \\
\left(\mathrm{mgkg}^{-1}\right)\end{array}$ & $\begin{array}{c}\text { Roots Metal } \\
\text { Content } \\
\left(\mathrm{mgkg}^{-1}\right)\end{array}$ & $\begin{array}{l}\text { Plants Total } \\
\text { Metal Content } \\
\left(\mathrm{mgkg}^{-1}\right)\end{array}$ \\
\hline \multirow{5}{*}{$\mathrm{Cu}$} & 0 & 0.46 & 2.22 & 0.86 & 4.53 \\
\hline & 50 & 0.27 & 7.13 & 5.28 & 12.83 \\
\hline & 100 & 1.93 & 3.46 & 0.64 & 4.75 \\
\hline & 150 & 2.08 & 3.21 & 10.45 & 16.21 \\
\hline & LSD $(P<0.05)$ & NS & NS & 4.74 & 5.29 \\
\hline
\end{tabular}

NS=Not significant.

$\mathrm{Cu}$ contents of Kenaf grown in the different levels of $\mathrm{Cu}$ treatments also showed significant differences at $P<0.01$ and the amount ranged from 4.53 to $16.21 \mathrm{mgkg}^{-1}$ (Table 8). However, the sequence of $\mathrm{Cu}$ accumulation in Kenaf plant was: root > stem > leaf.

\section{DISCUSSIONS}

\section{Soil physicochemical characteristics}

The significant decrease of soil $\mathrm{pH}$ with increasing levels of treatment, especially at the treatment level of $150 \mathrm{mg}$ $\mathrm{kg}^{-1} \mathrm{Cu}$ indicates that, where there are higher levels of toxicity or contamination, soil $\mathrm{pH}$ will reduce making soil more acidic. Similar observation was also reported by Akan et al. (2010) and Babatunde and Kamar (2010) where they observed that $\mathrm{pH}$ decreased significantly (increased soil acidity with higher concentration of heavy metals). Soil electrical conductivity (EC), though varied significantly, no treatment recorded EC values that are less than two $(<2)$, in other words soil still remained nonsaline according to the rating scale of Boulding (1994). Percent OC content of the soil was generally low before and after the laboratory contamination. Extractable $\mathrm{Cu}$ contents of soils treated with different levels of $\mathrm{Cu}$ was insignificant although the content is increased. This is expected because, with increase in the sources of contamination of pollution in the environment, the levels or concentration of pollutants (in this case heavy metals) will increase in the soil. Similar circumstance was reported by Babatunde and Suleiman (2010) where the concentration/contents of residual metal in the soil after harvest of Hibiscus cannabinus increased with the increasing levels of metal concentration.

Total $\mathrm{Cu}$ contents at all levels of treatments increased significantly with the increasing levels of treatments. Meaning, the higher the level of contamination, the more the concentration expected in the soil as earlier suggested by the study of Babatunde and Suleiman (2010). Not only that, heavy metals do not degrade in the environment or soil quickly which can result in accumulation as supported by the studies of van Herk (2012) and Akan et al. (2010).

\section{Agronomic performance and contents of $\mathrm{Cu}$ in Kenaf}

Growth rate of Kenaf in $\mathrm{Cu}$ treated soils were generally slow. Though plant heights were reduced insignificantly $(P$ $<0.05$ ) with increase in levels of $\mathrm{Cu}$ treatment. Kenaf showed toxicity symptoms which included yellowing of plant and stunted growth and even recorded death at levels of $100 \mathrm{mgkg}^{-1}$ and $150 \mathrm{mgkg}^{-1} \mathrm{Cu}$ treatments. The toxicity at this level was reported earlier in the study of van Herk (2012). Consequently, the growth rates of the plant reflected in the fresh and dry weights of Kenaf grown in $\mathrm{Cu}$ treated soil at all levels significantly $(P<0.05)$. Kenaf at the highest levels of $\mathrm{Cu}$ treated soil $\left(150 \mathrm{mgkg}^{-1}\right)$ weighed the least due to poor growth, toxicity and even death. Furthermore, the concentration of $\mathrm{Cu}$ reducing budding and growth rate of Kenaf as shown by lhekeronye and Ngoddy (1985) influenced the overall biomass of the plant.

Total plant $\mathrm{Cu}$ content of Kenaf grown in Cu treated soil was significantly $(P<0.05)$ increased with the increasing 
levels of treatment. Leaf, stem and root $\mathrm{Cu}$ contents also increased with the increasing levels of $\mathrm{Cu}$ treatments. This phenomenon was due to the increased exchangeable form of metal concentrations in soil, resulting in increased plant uptake. The studies of van Herk (2012) and Amusan et al. (1999) supported this finding, They reported that plants (Okra, Kenaf, Waterleaf) grown on dump sites with high concentrations of heavy metals had high uptake and concentrations in the plant tissues than those grown on non-dump sites. Another factor for increased uptake and accumulation of $\mathrm{Cu}$ in tissue of plant in this study might be the $\mathrm{pH}$ levels of the soil which generally were moderately acidic. van Herk (2012) and Zornoza et al. (2010) in their study indicated that acidity range of soil is known to increase the mobilization of heavy metals, thus increasing their uptake. An earlier study of Smith and Giller (1992) also showed that soil $\mathrm{pH}$ is one of the factors that influence bioavailability and transport of heavy metals in the soil which influence plant uptake.

\section{Conclusion}

Kenaf (Hibiscus cannabinus) was found as a potential hyperaccumulator or phytoextractant of $\mathrm{Cu}$ for the remediation of contaminated soil. However, the plant grown showed severe symptoms of toxicity from the level of $100 \mathrm{mgkg}^{-1} \mathrm{Cu}$ and even death at $150 \mathrm{mgkg}^{-1} \mathrm{Cu}$. Concentrations in plants of $\mathrm{Cu}$ was generally lower than anticipated. Therefore, more cycles of growth are needed to effectively remediate this metal from contaminated soils by Kenaf plant. At all treatment levels, soil physicochemical properties were generally not changed.

\section{CONFLICT OF INTEREST}

The authors declare that they have no conflict of interest.

\section{REFERENCES}

Abrol, I. P., Alvo, P., De Coninck, F., Eswaran, H., Fausey, N. R., Gupta, R. K., \& Young, I. M. (2012). Advances in Soil Science: Soil Degradation (Vol. 11). Springer Science \& Business Media.

Akan, J. C., Abdulrahman, F. I., Sodipo, O. A., \& Lange, A. G. (2010). Physicochemical Parameters in Soil and Vegetable Samples from Gongulon Agricultural Site, Maiduguri- Borno State, Nigeria. Journal of American Science, 6 (12), 78-87.

Amusan, A. A., Ige, P. V., \& Olawale, R. (1999). Preliminary investigation on the use of municipal waste dump for farming Paper presented at the 25th annual conference of soil science society of Nigeria held November 21-25, 1999. Benin city, Nigeria.

Arbaoui, S., Evlard, A., Mhamdi, M. E. W., Campanella, B., Paul, R., \& Bettaieb, T. (2013). Potential of kenaf (Hibiscus cannabinus L.) and corn (Zea mays L.) for phytoremediation of dredging sludge contaminated by trace metals. Biodegradation, 24(4), 563-567.
Aysha, M. I. J., Zakir, H. M., Haque, R., Quadir, Q. F., Choudhury, T. R., Quraishi, S. B. \& Mollah, M. Z. I. (2017). Health risk assessment for population via consumption of vegetables grown in soils artificially contaminated with arsenic. Archives of Current Research International, 10(3), 1-12.

Babatunde, S. B., \& Kamar A. R. (2010). Phytoremediation potential of kenaf (Hibiscuscannabinus L.) grown in different soil textures and cadmium concentrations. African Journal of Environmental Science and Technology 4(5), 250-255.

Babatunde, S.B. and Suleiman, T.K. (2010). Response of Kenaf (Hibiscus cannabinus L.) grown in different soil textures and lead concentration. Research Journal of Agriculture and Biological Science, 6(5), 659-664.

Bakali, B., Mia, M. Y., \& Zakir, H. M. (2014). Water quality evaluation of Tongi area in Bangladesh: an impact of industrialization. Journal of Chemical, Biological and Physical Sciences, 4(2), 1735-1752.

Begum, K., Mohiuddin, K. M., Zakir, H. M., Rahman, M., \& Hasan, M. N. (2014). Heavy metal pollution and major nutrient elements assessment in the soils of Bogra city in Bangladesh. Canadian Chemical Transactions, 2(3), 316-326.

Boulding, J. R. (1994). Description and sampling of contaminated soils: a field guide. CRC Press.

Climate Chart (2010). Maiduguri, Nigeria: Climate Global Warming and Daylight Charts and Data. Available at: http://www.climate-charts.com/Locations/n/NI65082.php. Accessed 23rd April, 2014.

Dalman, Ö., Demirak, A., \& Balcı, A. (2006). Determination of heavy metals $(\mathrm{Cd}, \mathrm{Pb})$ and trace elements $(\mathrm{Cu}, \mathrm{Zn})$ in sediments and fish of the Southeastern Aegean Sea (Turkey) by atomic absorption spectrometry. Food Chemistry, 95(1), 157-162.

Ghrefat, H., \& Yusuf, N. (2006). Assessing Mn, Fe, Cu, Zn, and Cd pollution in bottom sediments of Wadi Al-Arab Dam, Jordan. Chemosphere, 65(11), 2114-2121.

Grema, A. K., \& Hess, T. M. (1994). Water balance and water use of pearl millet-cowpea intercrops in north east Nigeria. Agricultural water management, 26(3), 169-185.

Haque, R., Zakir, H. M., Aysha, M. I. J., Supti, M., \& Shahinur, M. R. (2018). Heavy metal uptake pattern and potential human health risk through consumption of tomato grown in industrial contaminated soils. Asian Journal of Advances in Agricultural Research, 5(4), 1-11.

Hu, Y., Liu, X., Bai, J., Shih, K., Zeng, E. Y., \& Cheng, H. (2013). Assessing heavy metal pollution in the surface soils of a region that had undergone three decades of intense industrialization and urbanization. Environmental Science and Pollution Research, 20(9), 6150-6159.

Human Rights Watch (Organization) Staff (2013). World Report 2013: Events of 2012. Policy Press.

Ihekeronye, A. I., \& Ngoddy, P. O. (1985). Integral Food Science and technology for the Tropics.

Kaushik, G. (Ed.). (2015). Applied Environmental Biotechnology: Present Scenario and Future Trends. New Delhi, Springer India.

Logan, T. J. (1990). Chemical degradation of soil. In Advances in Soil Science, Pp. 187-221. Springer New York.

McLean, E. O. (1965). Aluminum. Methods of Soil Analysis. Part 2. Chemical and Microbiological Properties, (methodsofsoilanb), Pp. 978-998.

Mmolawa, K. B., Likuku, A. S., Gaboutloeloe, G. K., Adipala, E., Tusiime, G., \& Majaliwa, J. G. M. (2010). Study of heavy metal contamination along roadside soils of Botswana. In Second RUFORUM Biennial Regional Conference on "Building 
capacity for food security in Africa", Entebbe, Uganda, 20-24 September 2010. Pp. 735-738.

Pivetz, B. E. (2001). Phytoremediation of contaminated soil and ground water at hazardous waste sites. United States Environmental Protection Agency, Office of Research and Development, Office of Solid Waste and Emergency Response: Superfund Technology Support Center for Ground Water, National Risk Management Research Laboratory, Subsurface Protection and Remediation Division, Robert S. Kerr Environmental Research Center.

Rayar, A. J. (1984). University of Maiduguri Farm Development Planning Report for Faculty of Agriculture. Annex A. Soil survey details, Univ. Maiduguri Press, Nigeria.

Singh, D., Vyas, P., Sahni, S., \& Sangwan, P. (2015). Phytoremediation: A Biotechnological Intervention. In Applied Environmental Biotechnology: Present Scenario and Future Trends, Springer India. Pp. 59-75.

Smith, S. R., \& Giller, K. E. (1992). Effective Rhizobium leguminosarum biovar trifolii present in five soils contaminated with heavy metals from long-term applications of sewage sludge or metal mine spoil. Soil Biology and Biochemistry, 24(8), 781-788.

Soil Survey Staff (2014). Soil survey laboratory methods manual. Soil Survey Investigations Report No. 42 Version 5.0. U.S. Govt. Print. Office, Washington, DC.

Sparks, D. L., Page, A. L., Helmke, P. A., Loeppert, R. H., Soltanpour, P. N., Tabatabai, M. A., \& Sumner, M. E. (1996). Methods of soil analysis. Part 3-Chemical methods. Soil Science Society of America Inc..

Stover, R. C., Sommers, L. E., \& Silviera, D. J. (1976). Evaluation of metals in wastewater sludge. Journal (Water Pollution Control Federation), Pp. 2165-2175.

Tahar, K., \& Keltoum, B. (2011). Effects of heavy metals pollution in soil and plant in the industrial area, West ALGERIA. Journal of the Korean Chemical Society, 55(6), 1018-1023.

Tahar, K., Keltoum, B., \& Abderrazzak, B. A. (2014). The accumulation of some toxic metals in food plants near a polluted site. International Journal of Research and Reviews in Applied Sciences, 18(1), 51.
Thomas, G. W. (1996). Sol pH and soil acidity. In: Sparks DL (ed) Methods of soil analysis. Part 3. Chemical methods. SSSA and ASA. Madison, WI. Pp. 475-490.

van Herk, A. (2012). Physicochemical Parameters in Soil and Vegetable Samples from Gongulon Agricultural Site, Maiduguri, Borno State, Nigeria. International Journal of Chemistry, 01.

Walkley, A., \& Black, I. A. (1934). An examination of the Degtjareff method for determining soil organic matter, and a proposed modification of the chromic acid titration method. Soil science, 37(1), 29-38.

Zakir, H. M., Islam, M. M., \& Hossain, M. S. (2017). Heavy metal contents in sediments of an urban industrialized area- a case study of Tongi canal, Bangladesh. Asian Journal of Water, Environment and pollution, 14(1), 59-68.

Zakir, H. M., Rahman, M. M., Rahman, A., Ahmed, I., \& Hossain, M. A. (2012). Heavy metals and major ionic pollution assessment in waters of midstream of the river Karatoa in Bangladesh. Journal Environmental Science and Natural Reseources, 5(2), 149-160.

Zornoza, R., Carmona, D. M., Rosales, R. M., Faz, Á., BüYükkiliç, A., Kabas, S., \& Zanuzzi, A. (2010). Monitoring soil properties and heavy metals concentrations in reclaimed mine soils from SE Spain by application of different amendments. In 19th World Congress of Soil Science, Soil Solutions for a Changing World, Brisbane. Pp. 1-6. 